\title{
STRATEGI PENINGKATAN EMPLOYEE ENGAGEMENT MELALUI PROGRAM FLEXIBLE BENEFIT PT BNI (PERSERO) TBK KCU BOGOR
}

\author{
Shindy Aprilianingsih ${ }^{1)}$, Lindawati Kartika ${ }^{2) \bowtie}$
}

Departemen Manajemen, Institut Pertanian Bogor

\begin{tabular}{|c|c|}
\hline Info Artikel & Abstrak \\
\hline & Persentase angkatan kerja boomers, generasi $\mathrm{X}$, dan $\mathrm{Y}$ didominasi oleh \\
\hline $\begin{array}{l}\text { Diserahkan Juli } 2020 \\
\text { Diterima September } 2021 \\
\text { Diterbitkan September } \\
2021\end{array}$ & $\begin{array}{l}\text { generasi Y sebesar 51\% (BPS, 2017) dari total angkatan kerja di Indonesia tahun 2015-2017, begitu } \\
\text { juga dengan PT BNI (Persero) Tbk KCU Bogor yaitu sebesar 70\% karyawan generasi Y. Tujuan } \\
\text { penelitian ini adalah: (1) Mengidentifikasi persepsi karyawan tentang program flexible benefit. (2) } \\
\text { Mengidentifikasi employee engagement. (3) Menganalisis strategi meningkatkan employee engagement } \\
\text { melalui program flexible benefit. Analisis data menggunakan analisis deskriptif dan Analytical } \\
\text { Hierarchy Process (AHP) Hasil nenelitian menuniukan bahwa strategi meningkatkan emplovee }\end{array}$ \\
\hline $\begin{array}{l}\text { Kata Kunci: } \\
\text { Analytical Hierarchy } \\
\text { Process, Employee } \\
\text { Engagement, Flexible } \\
\text { Benefit }\end{array}$ & $\begin{array}{l}\text { engagement melalui program flexible benefit sebagai instrumen tambahan dalam mempertahankan } \\
\text { karyawan terbaik layak untuk dilanjutkan dengan aspek dedication sebagai faktor terpenting dan } \\
\text { alternatif strategi terpenting adalah fokus pada pengembangan karyawan, melalui empat program } \\
\text { prioritas lainnya, yaitu BNI Learning Wallet (BLW), BINNOVA, BNI Expert Locator, dan Shared } \\
\text { Office. }\end{array}$ \\
\hline
\end{tabular}

(C) 2021 Indonesia 


\section{Pendahuluan}

Menurut De Meuse et al., (2012), terdapat empat generasi angkatan kerja dalam perusahaan, yakni matures (1909-1945), boomers (1946-1964), generasi X (1965-1979), dan generasi Y (1980-2000). Demografi angkatan kerja yang bekerja di Indonesia mayoritas adalah penduduk kelahiran tahun 1980 sampai 2000 yang kemudian jika dikategorikan ke dalam era generasi berdasarkan tahun kelahiran merupakan generasi Y. Hal tersebut dapat dilihat pada Gambar 1.

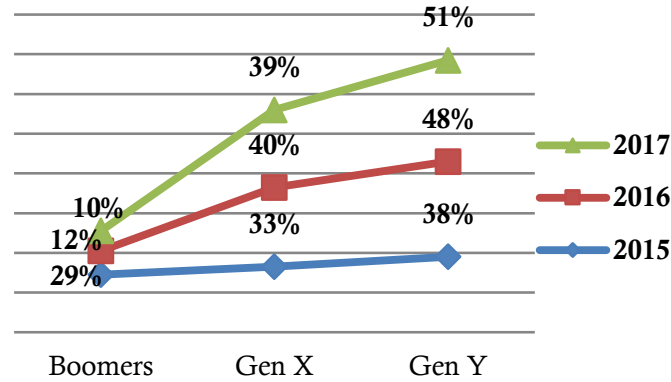

Gambar 1. Persentase Angkatan Kerja di Indonesia berdasarkan Generasi

Berdasarkan Gambar 1, dapat dilihat bahwa angkatan kerja generasi Y tahun 2017 di Indonesia sebesar $51 \%$ dari total jumlah angkatan kerja di Indonesia. Hal tersebut menunjukan bahwa angkatan kerja generasi Y mendominasi dibandingkan generasi $\mathrm{X}$ dan boomers. Generasi Y memiliki karakteristik peduli terhadap teknologi baru sesuai dengan perkembangan dunia dan memiliki kecenderungan yang rendah terhadap komitmen dan loyalitas dalam bekerja (Oktariani et al., 2017). Hal tersebut membuat perusahaan harus melakukan penyesuaian terhadap perubahan karakteristik generasi angkatan kerja. Tidak terkecuali PT BNI (Persero) Tbk KCU Bogor yang memiliki proporsi angkatan kerja generasi Y sebesar 70\% (BNI 2017). Hal tersebut dapat dilihat pada Gambar 2.

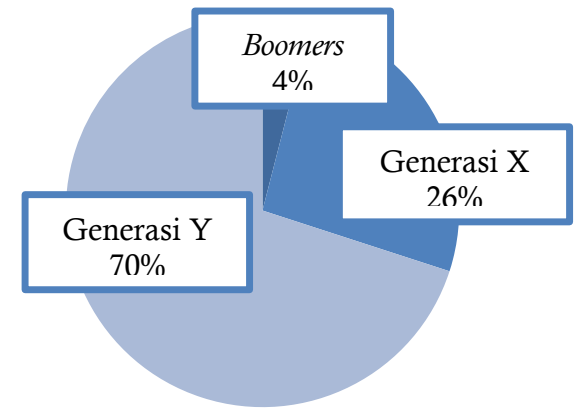

Gambar 2. Persentase Angkatan Kerja di PT BNI (Persero) Tbk KCU Bogor berdasarkan Generasi dari Populasi 50 Karyawan
PT BNI (Persero) Tbk KCU Bogor memiliki jumlah karyawan sebanyak 50 orang (BNI, 2017). Berdasarkan Gambar 2, dapat diketahui bahwa masih terdapat angkatan kerja boomers dan generasi X di PT BNI (Persero) Tbk KCU Bogor, yaitu sebesar 4\% dan 26\%. Angkatan kerja di PT BNI (Persero) Tbk KCU Bogor didominasi oleh generasi Y sebesar 70\% dari total jumlah karyawan.

PT BNI (Persero) Tbk KCU Bogor selalu percaya bahwa karyawan merupakan salah satu aset paling berharga bagi organisasi dan perusahaan manapun (BNI, 2017). Hal tersebut membuat BNI harus melakukan penyesuaian terhadap perubahan yang terjadi melalui program-program terbaik bagi karyawan, salah satu programnya adalah flexible benefit. Program flexible benefit merupakan program terbaru yang diimplementasikan oleh PT BNI (Persero) Tbk KCU Bogor. Program flexible benefit merupakan skema benefit yang memungkinkan karyawan untuk melakukan pemilihan terhadap benefit yang dinilai paling sesuai dengan kebutuhannya (BNI, 2017).

Terciptanya program flexible benefit bukan hanya untuk melakukan penyesuaian terhadap perubahan, melainkan sebagai salah satu cara PT BNI (Persero) Tbk dalam melakukan pengelolaan sumber daya manusia yang baik. Dalam suatu perusahaan, pengelolaan sumber daya manusia yang baik dapat menumbuhkan sifat positif dan adanya rasa keterikatan antara karyawan dengan perusahaan. Ketika karyawan bekerja dengan sepenuh hati untuk meningkatkan produktivitas perusahaan dan keuntungan dari perusahaan dengan memerlukan hubungan dua arah antara atasan dan bawahan dapat disebut dengan employee engagement (Robinson et al., 2004). Terdapat tiga aspek engagement yang digunakan dalam penelitian ini (Schaufeli et al., 2004), yaitu (1) Vigor merupakan aspek yang ditandai dengan tingkat tinggi energi dan ketahanan mental saat bekerja, semangat yang ditunjukan seseorang untuk melakukan pekerjaannya yang dapat dilihat dari stamina dan energi yang tinggi ketika bekerja; (2) Dedication meliputi keterlibatan tinggi terhadap pekerjaan, mengalami rasa penuh makna dan antusiasme yang ditandai dengan memperlihatkan ketertarikan terhadap pekerjaan yang dilakukan, serta kebanggaan terhadap pekerjaan; (3) Absorption merupakan aspek yang mengacu pada konsentrasi dan keseriusan dalam bekerja, menikmati pekerjaan sehingga waktu terasa berlalu begitu cepat ketika sedang bekerja. Karyawan yang mempunyai engagement yang tinggi akan merasa nyaman dalam 
lingkungan kerjanya sehingga menurunkan keinginan untuk berpindah. PT BNI (Persero) Tbk KCU Bogor memiliki level dari employee engagement yang baik. Hal tersebut mengindikasikan bahwa karyawan memiliki engagement yang cukup kuat dengan perusahaan, sehingga keengganan karyawan untuk keluar dari perusahaan. Indeks Employee Engagement Survey (EES) PT BNI (Persero) Tbk KCU Bogor dapat dilihat pada Gambar 3.

\section{1}

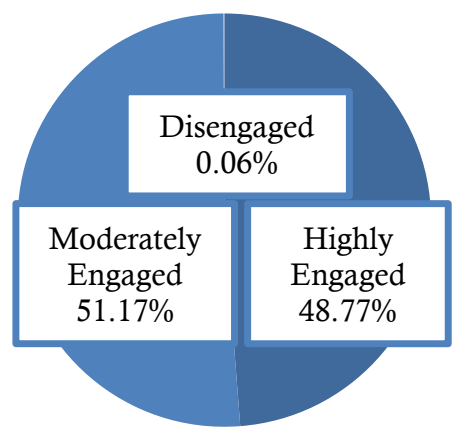

2014

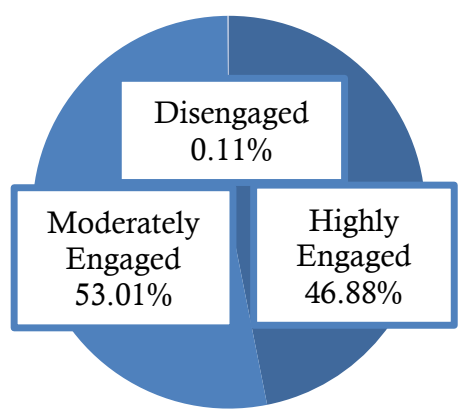

2016

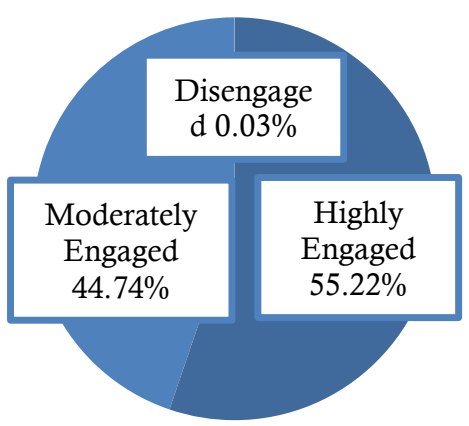

Gambar 3. Employee Engagement Survey PT BNI (Persero) Tbk

Berdasarkan Gambar 3, dapat diketahui bahwa employee engagement survey PT BNI (Persero) Tbk KCU Bogor dari tahun 2011 sampai 2014 mengalami penurunan sebesar 1.89\%. Sedangkan dari tahun 2014 sampai 2016 mengalami peningkatan yang signifikan sebesar 8.34\%. Pada dasarnya masing-masing karyawan memiliki kebutuhan yang berbeda. Sebelumnya, PT BNI (Persero) Tbk KCU Bogor memiliki sistem pemberian jenis benefit yang sama kepada karyawan dan tidak terpaku pada suatu program benefit. Oleh karena itu, PT BNI (Persero) Tbk KCU Bogor melakukan inovasi dalam hal kompensasi finansial, khususnya kompensasi tidak langsung menjadi flexible benefit. Flexible benefit merupakan skema benefit yang memungkinkan karyawan untuk melakukan pemilihan terhadap benefit yang dinilai paling sesuai dengan kebutuhannya (BNI, 2017).

Berdasarkan pemaparan tersebut, maka tujuan pada penelitian ini sebagai berikut: (1) Mengidentifikasi persepsi karyawan PT BNI (Persero) Tbk KCU Bogor terhadap employee engagement, (2) Mengidentifikasi persepsi karyawan PT BNI (Persero) Tbk KCU Bogor terhadap program flexible benefit, Menganalisis strategi meningkatkan employee engagement PT BNI (Persero) Tbk KCU Bogor melalui program flexible benefit. Metode pengolahan data menggunakan analisis deskriptif dengan teknik modus dan Analytical Hierarchy Process (AHP). Perhitungan AHP dibantu dengan software Expert Choice 2011.

\section{Metode}

Penelitian ini dilakukan di PT BNI (Persero) Tbk KCU Bogor yang berlokasi di Jalan Ir. H. Juanda No. 52, Kota Bogor, Jawa Barat. Jenis penelitian ini adalah penelitian deskriptif menggunakan pendekatan kuantitatif. Responden dalam penelitian ini terbagi menjadi dua, yaitu karyawan tetap pada level staff yang sudah menggunakan program flexible benefit dan pakar yang dianggap ahli dalam bidang Sumber Daya Manusia dan flexible benefit. Penentuan sampel menggunakan non-probability sampling dengan teknik purposive sampling. Metode pengolahan data menggunakan analisis deskriptif dengan teknik modus dan Analytical Hierarchy Process (AHP). Perhitungan AHP dibantu dengan software Expert Choice 2011. Rentang skala untuk mendeskripsikan hasil analisis deskriptif dengan teknik modus terdapat pada Tabel 1. 
Tabel 1. Rentang Skala Analisis Deskriptif menggunakan Modus

\begin{tabular}{cc}
\hline Rentang Skala & Keterangan \\
\hline $0-25 \%$ & Sangat Tidak Baik \\
$>25 \%-50 \%$ & Tidak Baik \\
$>50 \%-75 \%$ & Baik \\
$>75 \%-100 \%$ & Sangat Baik \\
\hline
\end{tabular}

Sumber: (Sugiyono, 2014) (data diolah 2018)

Berdasarkan Tabel 1, jika nilai modus berada pada rentang skala $0-25 \%$ karyawan menyatakan sangat tidak baik, nilai modus berada pada rentang skala $>25 \%-50 \%$ karyawan menyatakan tidak baik, nilai modus berada pada rentang skala $>50 \%-75 \%$ karyawan menyatakan baik, dan jika nilai modus berada pada rentang skala $>75 \%-100 \%$ karyawan menyatakan sangat baik.

\section{Hasil dan Pembahasan}

3.1 Hasil Analisis Deskriptif Persepsi Karyawan PT BNI (Persero) Tbk KCU Bogor terhadap Employee Engagement

Aspek-aspek dari employee engagement terdiri dari tiga dimensi, yaitu aspek vigor, aspek dedication, dan aspek absorption (Schaufeli et al., 2004). Hasil rekapitulasi analisis deskriptif persepsi karyawan PT BNI (Persero) Tbk KCU Bogor mengenai employee engagement dapat dilihat pada Tabel 2.

Tabel 2. Hasil Analisis Deskriptif Aspek Employee Engagement dengan Modus

\begin{tabular}{|c|c|c|c|c|c|c|c|}
\hline \multirow{3}{*}{ Kode } & \multirow{3}{*}{ Pernyataan } & \multicolumn{4}{|c|}{ Jawaban Responden } & \multirow{3}{*}{$\begin{array}{c}\text { Modus }(3,4) \\
(\%)\end{array}$} & \multirow{3}{*}{ Keterangan } \\
\hline & & 1 & 2 & 3 & 4 & & \\
\hline & & $\begin{array}{l}\text { STS } \\
(\%)\end{array}$ & $\begin{array}{l}\text { TS } \\
(\%)\end{array}$ & $\begin{array}{c}\mathrm{S} \\
(\%)\end{array}$ & $\begin{array}{l}\text { SS } \\
(\%)\end{array}$ & & \\
\hline \multicolumn{8}{|l|}{ Vigor } \\
\hline EE1 & $\begin{array}{l}\text { Berenergi dan berstamina tinggi saat } \\
\text { bekerja }\end{array}$ & 0 & 0 & 73.529 & 26.471 & 100 & Sangat baik \\
\hline EE2 & Semangat dan kuat saat bekerja & 0 & 0 & 76.471 & 23.529 & 100 & Sangat baik \\
\hline EE5 & Ulet dalam bekerja & 0 & 5.882 & 76.471 & 17.647 & 94.118 & Sangat baik \\
\hline EE3 & $\begin{array}{l}\text { Senang datang ke tempat kerja saat } \\
\text { bangun pagi hari }\end{array}$ & 0 & 5.882 & 79.412 & 14.706 & 94.118 & Sangat baik \\
\hline EE6 & $\begin{array}{l}\text { Tekun dalam bekerja ketika sesuatu } \\
\text { tidak berjalan baik }\end{array}$ & 0 & 2.941 & 82.353 & 14.706 & 97.059 & Sangat baik \\
\hline EE4 & Kuat bekerja dalam waktu yang lama & 0 & 8.824 & 85.294 & 5.882 & 91.176 & Sangat baik \\
\hline \multicolumn{8}{|c|}{ Dedication } \\
\hline EE7 & $\begin{array}{l}\text { Pekerjaan yang dilakukan penuh } \\
\text { makna dan tujuan }\end{array}$ & 0 & 0 & 76.471 & 23.529 & 100 & Sangat baik \\
\hline EE10 & Rasa bangga terhadap pekerjaan & 0 & 5.882 & 73.529 & 20.588 & 94.118 & Sangat baik \\
\hline EE11 & Pekerjaan menantang & 0 & 5.882 & 73.529 & 20.588 & 94.118 & Sangat baik \\
\hline EE8 & Antusias terhadap pekerjaan & 0 & 5.882 & 79.412 & 14.706 & 94.118 & Sangat baik \\
\hline EE9 & Terinsipirasi oleh pekerjaan & 0 & 5.882 & 79.412 & 14.706 & 94.118 & Sangat baik \\
\hline \multicolumn{8}{|c|}{ Absorption } \\
\hline EE12 & $\begin{array}{l}\text { Waktu berlalu dengan cepat saat } \\
\text { bekerja }\end{array}$ & 0 & 8.824 & 79.412 & 11.765 & 91.176 & Sangat baik \\
\hline EE14 & Rasa bahagia ketika bekerja & 0 & 5.882 & 91.176 & 2.941 & 94.118 & Sangat baik \\
\hline EE13 & $\begin{array}{l}\text { Melupakan hal-hal sekitar saat } \\
\text { bekerja }\end{array}$ & 0 & 29.412 & 70.588 & $\mathbf{0}$ & 70.588 & Baik \\
\hline EE15 & Tenggelam dalam pekerjaan & 0 & 41.176 & 58.824 & $\mathbf{0}$ & 58.824 & Baik \\
\hline EE16 & Terbawa suasana saat bekerja & 0 & 38.235 & 61.765 & $\mathbf{0}$ & 61.765 & Baik \\
\hline EE17 & Sulit melepaskan diri dari pekerjaan & 0 & 52.941 & 47.059 & $\mathbf{0}$ & 47.059 & Baik \\
\hline
\end{tabular}

Berdasarkan Tabel 2, diketahui bahwa mayoritas persepsi karyawan PT BNI (Persero) Tbk KCU Bogor mengenai aspek-aspek employee engagement pada perusahaan dapat dikatakan baik. Pada aspek vigor, pernyataan memiliki energi dan stamina tinggi ketika bekerja menjadi pernyataan dominan. Hal tersebut sesuai dengan karakteristik respoden yang merupakan angkatan kerja generasi Y, dimana generasi Y 
merupakan angkatan kerja yang dapat dikatakan berada pada usia produktif untuk bekerja. Pernyataan dominan pada aspek dedication, yaitu karyawan merasa pekerjaan yang dilakukan penuh makna dan tujuan. Hal tersebut menunjukan bahwa karyawan PT BNI (Persero) Tbk KCU Bogor menghargai pekerjaannya dan mau memberikan kontribusi yang besar bagi pekerjaannya demi meraih tujuan. Pada aspek absorption, pernyataan saat bekerja merasa waktu berlalu dengan cepat menjadi pernyataan dominan. Hal tersebut dikarenakan karyawan PT BNI (Persero) Tbk $\mathrm{KCU}$ Bogor bekerja dengan penuh keseriusan dan fokus ketika bekerja.
3.2 Hasil Analisis Deskriptif Persepsi Karyawan PT BNI (Persero) Tbk KCU Bogor mengenai Program Flexible Benefit

Program flexible benefit merupakan skema benefit yang memungkinkan karyawan untuk melakukan pemilihan terhadap benefit yang dinilai paling sesuai dengan kebutuhannya. Program flexible benefit merupakan salah satu program baru yang diimplementasikan oleh PT BNI (Persero) Tbk KCU Bogor untuk karyawan tetap. Hasil rekapitulasi analisis deskriptif persepsi karyawan PT BNI (Persero) Tbk KCU Bogor terhadap program flexible benefit dapat dilihat pada Tabel 3.

Tabel 3. Hasil Analisis Deskriptif Periode Program Flexible Benefit dengan Modus

\begin{tabular}{|c|c|c|c|c|c|c|c|}
\hline \multirow{3}{*}{ Kode } & \multirow{3}{*}{ Pernyataan } & \multicolumn{4}{|c|}{ Jawaban Responden } & \multirow{3}{*}{$\begin{array}{c}\text { Modu } \\
\text { s }(3,4) \\
(\%)\end{array}$} & \multirow{3}{*}{ Ket. } \\
\hline & & 1 & 2 & 3 & 4 & & \\
\hline & & STS $(\%)$ & $\begin{array}{c}\text { TS } \\
(\%)\end{array}$ & $\begin{array}{c}\mathrm{S} \\
(\%)\end{array}$ & $\begin{array}{l}\text { SS } \\
(\%)\end{array}$ & & \\
\hline \multicolumn{8}{|c|}{ Periode Enrollment } \\
\hline FB4 & Formulir klaim benefit mudah diakses & 0 & 0 & 85.294 & 14.706 & 100 & $\begin{array}{c}\text { Sangat } \\
\text { baik }\end{array}$ \\
\hline FB3 & $\begin{array}{l}\text { Ketersediaan formulir klaim benefit di } \\
\text { hucas.bni.co.id }\end{array}$ & 0 & 0 & 94.118 & 5.882 & 100 & $\begin{array}{c}\text { Sangat } \\
\text { baik }\end{array}$ \\
\hline FB6 & Kemudahan proses klaim benefit & 0 & 8.824 & 88.235 & 2.941 & $\begin{array}{c}91.17 \\
6\end{array}$ & $\begin{array}{c}\text { Sangat } \\
\text { baik }\end{array}$ \\
\hline FB2 & $\begin{array}{l}\text { Memahami prosedur periode } \\
\text { enrollment }\end{array}$ & 0 & 11.765 & 85.294 & 2.941 & $\begin{array}{c}88.23 \\
5\end{array}$ & $\begin{array}{c}\text { Sangat } \\
\text { baik }\end{array}$ \\
\hline FB5 & Kepuasan pada pilihan flex item & 0 & 11.765 & 85.294 & 2.941 & $\begin{array}{c}88.23 \\
5\end{array}$ & $\begin{array}{c}\text { Sangat } \\
\text { baik }\end{array}$ \\
\hline FB1 & $\begin{array}{l}\text { Mengetahui prosedur periode } \\
\text { enrollment }\end{array}$ & 0 & 20.588 & 76.471 & 2.941 & $\begin{array}{c}79.41 \\
2\end{array}$ & $\begin{array}{c}\text { Sangat } \\
\text { baik }\end{array}$ \\
\hline FB7 & Kepuasan proses periode enrollment & 0 & 11.765 & 88.235 & $\mathbf{0}$ & $\begin{array}{c}88.23 \\
5\end{array}$ & $\begin{array}{c}\text { Sangat } \\
\text { baik }\end{array}$ \\
\hline \multicolumn{8}{|c|}{ Periode Pemanfaatan Benefit } \\
\hline FB8 & $\begin{array}{l}\text { Mengetahui prosedur periode } \\
\text { pemanfaatan benefit }\end{array}$ & 0 & 0 & 85.294 & $\begin{array}{c}14.70 \\
6\end{array}$ & 100 & $\begin{array}{c}\text { Sangat } \\
\text { baik }\end{array}$ \\
\hline FB9 & $\begin{array}{l}\text { Memahami prosedur periode } \\
\text { pemanfaatan benefit }\end{array}$ & 0 & 11.765 & 79.412 & 8.824 & 88.235 & $\begin{array}{c}\text { Sangat } \\
\text { baik }\end{array}$ \\
\hline FB10 & $\begin{array}{l}\text { Pemanfaatan benefit dibagi menjadi } 4 \\
\text { kuartal }\end{array}$ & 0 & 0.00 & 91.176 & 8.824 & 100 & $\begin{array}{c}\text { Sangat } \\
\text { baik }\end{array}$ \\
\hline FB13 & Kecepatan proses dana reimbursement & 0 & 23.529 & 67.647 & 8.824 & 76.471 & $\begin{array}{c}\text { Sangat } \\
\text { baik }\end{array}$ \\
\hline FB11 & $\begin{array}{l}\text { Kemudahan berkas yang dibutuhkan } \\
\text { untuk reimbursement }\end{array}$ & 0 & 11.765 & 85.294 & 2.941 & 88.235 & $\begin{array}{c}\text { Sangat } \\
\text { baik }\end{array}$ \\
\hline FB12 & Kemudahan saat proses reimbursement & 0 & 23.529 & 73.529 & 2.941 & 76.471 & $\begin{array}{c}\text { Sangat } \\
\text { baik }\end{array}$ \\
\hline FB14 & $\begin{array}{l}\text { Kepuasan dengan implementasi } \\
\text { program }\end{array}$ & 0 & 11.765 & 85.294 & 2.941 & 88.235 & $\begin{array}{c}\text { Sangat } \\
\text { baik }\end{array}$ \\
\hline
\end{tabular}

Sumber: Kuesioner (data diolah 2018)

Secara garis besar, tahapan program flexible benefit dibagi menjadi dua periode, yaitu periode enrollment dan periode pemanfaatan benefit. Berdasarkan Tabel 3, diketahui bahwa mayoritas karyawan PT BNI (Persero) Tbk KCU Bogor sudah puas dengan implementasi dari program flexible benefit. Hal tersebut dibuktikan dari hasil perhitungan menggunakan modus, bahwa setiap pernyataan dari kedua periode sudah memiliki nilai modus yang berada pada posisi sangat baik. Hal lain yang membuktikan bahwa karyawan setuju atau puas dengan implementasi program flexible benefit, 
yaitu seluruh karyawan yang menjadi responden setuju jika program flexible benefit tetap diadakan untuk tahun-tahun berikutnya.

Berdasarkan persepsi karyawan PT BNI (Persero) Tbk KCU Bogor pada periode enrollment program flexible benefit, hasil menunjukan bahwa pernyataan mengenai formulir klaim benefit sangat mudah untuk diakses memiliki nilai modus tertinggi. Hal tersebut dikarenakan formulir klaim benefit dilakukan secara digital melalui www.hucas.bni.co.id, dimana semua karyawan tetap hanya perlu $\log$ in menggunakan user id dan password yang dimiliki. Tampilan dari formulir klaim benefit juga disajikan secara ringkas dan jelas. Pada periode pemanfaatan benefit, hasil menunjukan bahwa mengetahui prosedur periode pemanfaatan benefit memiliki nilai modus tertinggi. Hal tersebut dikarenakan selain sudah diberikannya sosialisasi yang baik oleh pihak perusahaan, karyawan juga familiar dengan istilah periode pemanfaatan benefit program flexible benefit.
3.3 Hasil Analisis Proses Hierarki Strategi Peningkatan Employee Engagement PT BNI (Persero) Tbk KCU Bogor melalui Program Flexible Benefit

\section{Hasil Pengolahan AHP Terhadap Level} Faktor

Faktor terpenting dalam meningkatkan employee engagement adalah aspek dedication dengan bobot sebesar 0.480. Peringkat kedua yang menjadi faktor dalam meningkatkan employee engagement adalah aspek vigor dengan bobot sebesar 0.367. Faktor dengan peringkat ketiga adalah aspek absorption dengan bobot sebesar 0.153. Berdasarkan syarat AHP yang harus memiliki nilai rasio konsistensi kurang dari 0.100 , hasil gabungan dari empat pakar untuk faktor meningkatkan employee engagement menghasilkan nilai rasio konsistensi sebesar 0.009. Hal tersebut menunjukan bahwa hasil AHP dari penggabungan pakar kurang dari 0.100 sehingga dapat dikatakan memenuhi syarat konsistensi perhitungan AHP. Hasil pengolahan AHP terhadap elemen faktor dapat dilihat pada Tabel 4.

Tabel 4. Hasil Pengolahan AHP terhadap Elemen Faktor

\begin{tabular}{|c|c|c|}
\hline Elemen Faktor & Bobot & Prioritas \\
\hline Aspek Vigor & 0.367 & 2 \\
\hline Aspek Dedication & 0.480 & 1 \\
\hline Aspek Absorption & 0.153 & 3 \\
\hline Consistency Rasio (CR) & \multicolumn{2}{|c|}{0.009} \\
\hline
\end{tabular}

Berdasarkan Tabel 4, aspek dedication menjadi faktor terpenting dalam meningkatkan employee engagement. Membuat karyawan merasa terikat dengan perusahaan merupakan hal yang sudah seharusnya diperhatikan oleh perusahaan. Keterlibatan tinggi karyawan terhadap pekerjaan dapat menjadi langkah penting yang harus dilakukan oleh perusahaan dalam mewujudkan aspek dedication karyawan. Hal tersebut dapat membuat karyawan merasa bahwa pekerjaan yang dilakukannya memiliki tujuan dan penuh makna. Selain itu, karyawan juga akan merasa antusias dan bangga dengan pekerjaannya. Dengan demikian karyawan akan terus berusaha memberikan yang terbaik bagi perusahaan dan merasa lebih memiliki rasa keterikatan yang tinggi dengan perusahaan.
Hasil Pengolahan AHP Terhadap Level Tujuan

Peringkat pertama tujuan diimplementasikannya program flexible benefit adalah sebagai instrumen tambahan dalam mempertahankan karyawan terbaik di bank dengan bobot sebesar 0.447. Elemen tujuan peringkat kedua dengan bobot sebesar 0.279 , yaitu meningkatkan efektivitas pemberian benefit bagi karyawan. Peringkat ketiga adalah menjadikan bank sebagai perusahaan pilihan utama bagi talent terbaik di pasar dengan bobot sebesar 0.154. Peringkat terakhir adalah meningkatkan reputasi bank sebagai perusahaan yang menerapkan effective best practices dalam pengelolaan sumber daya manusia dengan bobot sebesar 0.120 . Hasil gabungan dari empat pakar untuk tujuan diimplementasikannya program flexible benefit menghasilkan nilai konsistensi rasio sebesar 0.040. Hal tersebut menunjukan 
bahwa hasil dari penggabungan pakar kurang dari 0.100 sehingga dapat dikatakan memenuhi syarat konsistensi rasio perhitungan AHP. Hasil pengolahan AHP terhadap elemen tujuan dapat dilihat pada Tabel 5.

Tabel 5. Hasil Pengolahan AHP terhadap Elemen Tujuan

\begin{tabular}{lcc}
\hline \multicolumn{1}{c}{ Elemen Tujuan } & Bobot & Prioritas \\
\hline $\begin{array}{l}\text { Meningkatkan efektivitas pemberian benefit bagi karyawan. } \\
\begin{array}{l}\text { Menjadikan Bank sebagai perusahaan pilihan utama bagi talent terbaik di } \\
\text { pasar. }\end{array}\end{array}$ & 0.279 & 2 \\
$\begin{array}{l}\text { Sebagai instrumen tambahan dalam mempertahankan karyawan terbaik } \\
\text { di bank }\end{array}$ & $\mathbf{0 . 4 4 7}$ & $\mathbf{1}$ \\
$\begin{array}{l}\text { Meningkatkan reputasi bank sebagai perusahaan yang menerapkan effective } \\
\text { best practices dalam pengelolaan sumber daya manusia. }\end{array}$ & 0.120 & 4 \\
\hline Consistency Rasio (CR) & \multicolumn{2}{c}{0.040} \\
\hline
\end{tabular}

Sumber: Kuesioner (data diolah 2018)

Berdasarkan Tabel 5, tujuan terpenting diimplementasikannya program flexible benefit adalah sebagai instrumen tambahan dalam mempertahankan karyawan terbaik di perusahaan. Dengan adanya kebebasan dalam pemilihan benefit sesuai dengan kebutuhan karyawan yang berbeda-beda merupakan cara yang tepat dalam meningkatkan employee engagement dengan perusahaan. Program flexible benefit merupakan satu-satunya program yang baru diimplementasikan di perusahaan perbankan oleh PT BNI (Persero) Tbk KCU Bogor. Hal tersebut membuat PT BNI (Persero) Tbk KCU Bogor memiliki nilai tambah dibandingkan dengan perusahaan perbankan lainnya. Dengan begitu karyawan akan semakin loyal terhadap perusahaan.
Hasil Pengolahan AHP Terhadap Elemen Alternatif Strategi

Fokus pada pengembangan karyawan merupakan alternatif strategi terpenting dalam meningkatkan employee engagement dengan bobot sebesar 0.157. Hasil gabungan dari empat pakar untuk alternatif strategi meningkatkan employee engagement menghasilkan nilai konsistensi rasio sebesar 0.020. Hal tersebut menunjukan bahwa hasil penggabungan pakar kurang dari 0.100 sehingga memenuhi syarat konsistensi rasio perhitungan AHP. Hasil pengolahan AHP terhadap elemen alternatif strategi dapat dilihat pada Tabel 6.

Tabel 6. Hasil Pengolahan AHP terhadap Elemen Alternatif Strategi

\begin{tabular}{|c|c|c|c|}
\hline Elemen Alternatif & & Bobot & Prioritas \\
\hline Kualitas manajemen lini yang baik & & 0.092 & 8 \\
\hline Komunikasi terbuka secara dua arah & & 0.155 & 2 \\
\hline Kerjasama yang efektif dalam perusahaan & & 0.129 & 4 \\
\hline Fokus pada pengembangan karyawan & & 0.157 & 1 \\
\hline Komitmen terhadap kesejahteraan karyawan & & 0.126 & 5 \\
\hline Kebijakan dan praktik HR yang jelas & & 0.138 & 3 \\
\hline Keadilan dalam pembayaran dan tunjangan & & 0.097 & 7 \\
\hline Lingkungan kerja yang harmonis & & 0.106 & 6 \\
\hline Consistency Rasio (CR) & & \multicolumn{2}{|c|}{0.020} \\
\hline \multicolumn{4}{|l|}{ Sumber: Kuesioner (data diolah 2018) } \\
\hline $\begin{array}{l}\text { Berdasarkan Tabel 6, dalam } \\
\text { meningkatkan employee engagement alternatif } \\
\text { strategi yang harus diperhatikan adalah fokus } \\
\text { pada pengembangan karyawan. Memberikan } \\
\text { pelatihan dan pembinaan terhadap karyawan }\end{array}$ & $\begin{array}{l}\text { sesuai dengan } \\
\text { menunjang kompetensi } \\
\text { karyawan menjadi langkah } \\
\text { dilakukan perusahaan. } \mathrm{H} \\
\text { membuat karyawan dapat } \\
\text { dan merupakan cara yang }\end{array}$ & $\begin{array}{l}\text { kebutuh } \\
\text { si ma: } \\
\text { h penting } \\
\text { Hal ters } \\
\text { at terus } \\
\text { adil dal }\end{array}$ & $\begin{array}{r}\text { dalam } \\
\text {-masing } \\
\text { g harus } \\
\text { dapat } \\
\text { embang } \\
\text { peluang }\end{array}$ \\
\hline
\end{tabular}


pengembangan masing-masing karyawan. Selain itu, hal tersebut juga membuat karyawan merasa bahwa perusahaan memerhatikan pandangan jangka panjang terhadap kompetensi yang dimiliki oleh karyawan.

\section{Kesimpulan}

Hasil analisis dalam penelitian ini menyatakan bahwa karyawan PT BNI (Persero) Tbk KCU Bogor memiliki employee engagement yang sangat baik. Pada aspek vigor, pernyataan memiliki energi dan stamina tinggi ketika bekerja menjadi pernyataan dominan. Pernyataan dominan pada aspek dedication, yaitu karyawan merasa pekerjaan yang dilakukan penuh makna dan tujuan. Pada aspek absorption, pernyataan saat bekerja merasa waktu berlalu dengan cepat menjadi pernyataan dominan. Karyawan PT BNI (Persero) Tbk KCU Bogor sudah merasa puas dengan implementasi program flexible benefit, dimana setiap pernyataan dari kedua periode sudah memiliki nilai modus yang berada pada posisi sangat baik dan seluruh karyawan setuju jika program tetap diadakan. Strategi meningkatkan employee engagement melalui program flexible benefit sebagai instrumen tambahan dalam mempertahankan karyawan terbaik layak untuk dilanjutkan dengan aspek dedication sebagai faktor terpenting dan alternatif strategi terpenting adalah fokus pada pengembangan karyawan, melalui empat program prioritas lainnya, yaitu BNI Learning Wallet (BLW), BINNOVA, BNI Expert Locator, dan Shared Office.

\section{Ucapan Terima Kasih}

Ucapan terimakasih ditujukan kepada Lindawati Kartika SE, M.Si selaku dosen pembimbing, Dra. Siti Rahmawati, M. Pd selaku dosen penguji, Pihak PT BNI (Persero) Tbk KCU Bogor, serta berbagai pihak yang telah membimbing dan mengarahkan dalam penulisan karya tulis ini.

\section{Daftar Pustaka}

[BNI] Bank Negara Indonesia. 2017. Implementasi Program Flexible Benefit. Jakarta (ID): PT BNI (Persero) Tbk.

[BNI] Bank Negara Indonesia. 2017. Comprehensive Organization Profile PT BNI (Persero) Tbk. Jakarta (ID): PT BNI (Persero) Tbk.

[BPS] Badan Pusat Statistik. 2017. Penduduk Indonesia yang Bekerja Berdasarkan Golongan Umur dan Jumlah Jam Kerja.
De Meuse KP dan Mlodzik KJ. 2012. A Scholarly Investigation of Generational Workforce Differences: Debunking the Myths [internet].

Oktariani D, Hubeis AVS, dan Sukandar D. 2017. Kepuasan Kerja Generasi $X$ dan Generasi $Y$ terhadap Komitmen Kerja di Bank Mandiri Palembang. Jurnal Aplikasi Bisnis dan Manajemen [internet].

Robinson D, Perryman S, dan Hayday S. 2004. The Drivers of Employee engagement. Brighton (UK): Institute for Employment Studies.

Schaufeli WB, dan Bakker AB. 2004. Utrecth Work Engagement Scale (UWES) Preilinary Manual.

Sugiyono. 2014. Metode Penelitian Kombinasi (Mixed Method) Cetakan Ke-5. Bandung (ID): Alfabeta. 